\title{
Status and Analysis of Formal and Actual Human Resource Management, Financial and Policy Autonomy of State-Owned Enterprises in Pakistan
}

\author{
Muhammad Zeeshan Hanif \\ Institute of Administrative Sciences, University of the Punjab, PO box 54000, Pakistan
}

\begin{abstract}
This paper studies the formal and actual human resource management (HRM) autonomy, financial autonomy and policy autonomy of the state owned enterprises (SOEs) of Pakistan and points out the differences that exist between them. It also identifies behind the lack of autonomy of SOEs and proposes multiple recommendations though which this gap can be bridged. Both quantitative and qualitative data was collected to carry out this study. Quantitative data was collected from 40 randomly selected SOEs using a close-ended questionnaire while 20 semi-structured interviews were carried out to collect qualitative data. Descriptive statistics was used to see the number of SOEs having different levels of HRM autonomy, financial autonomy and policy autonomy. It was found that a very less number of SOEs were completely autonomous in different aspects of HRM, financial management, policy formulation and its implementation. Excessive political intervention, dependence on government for resources, lack of power of Security and Exchange Commission of Pakistan (SECP) and poor performance of SOEs along with numerous other reasons were identified as causes behind this lack of autonomy. Multiple recommendations have also been proposed to overcome this issue.
\end{abstract}

Keywords: Autonomy, State Owned Enterprises, Human Resource Management Autonomy, Financial Autonomy, Policy Autonomy, Task Autonomy, Securities and Exchange Commission of Pakistan, Companies Ordinance 1984, Public Sector Companies (Corporate Governance) Rules 2013.

DOI: $10.7176 / \mathrm{PPAR} / 10-1-01$

Publication date: January $31^{\text {st }} 2020$

\section{Introduction}

SOEs are legal entities that are created by the government under some act or law so that they can participate in any business on the behalf of the government or perform regulatory function. According to Boycko et al. (1996), Wintrobe (1987), Labra (1980) and Khan (2007), SOEs can be created in both industrialized mixed economies and in developing countries to act as an important instrument of social and economic policy and help in increasing employment, generating revenue, achieving some social goals, ensuring economic development and keeping the control of state over economy. SOEs are also seen to be operating to meet two apparently contradictory objectives which are to protect public interest and ensure economic goals (Aharoni, 1981). SOEs play more important role in the improvement of economy of developing countries as they are created for political, ideological and economic reasons (Smith and Trebilcock, 2001). Majority of the literature agrees that SOEs are given maximum autonomy so that they can function productively (Braadbaart et al., 2007). However, formal autonomy cannot always ensure the de facto autonomy or the autonomy that an organization can have in practice (Yesilkagit and Thiel, 2008). According to Aharoni (1986), Garner (2005) and Sexty (1980), the independent functioning of SOEs is considered as a cornerstone for their effective and efficient performance.

In Pakistan, the public corporations have been created by Federal and Provincial governments by special legislation under the Companies Act 1913 or Companies Ordinance 1984. SOEs in Pakistan have been created to perform vide range of functions like developing and controlling the industries that were built for strategic purposes in order to promote national interests, enhancing the export of important crops like cotton and rice, regulating the import of essential items, providing credit to industry, agriculture and businesses, creating capital and goods required for industrial engineering and also promoting the development of technological skills. Unfortunately, the current condition of SOEs of Pakistan is very alarming as they have become a burden on state's treasury due to poor performance and state has to constantly intervene in their functioning. According to Khan (2008), SOEs are suffering due to corruption, over employment, inflation, rising deficits and ineffective management. According to Rana (2011), the total number of staff of Pakistan Railways alone is 110,000 where as it can be efficiently run by only 40,000 employees. Similarly, in January 2014, the Pakistan Steel Mills was operating at three per cent of its capacity but its monthly salary bill was around Rs500 million because of over employment which resulted in a cumulative loss of Rs103 billion. Amount as big as Rs 400-600 billion was spent by the government on the SOEs annually to keep them in working condition (Chodhury, 2012). So much so that in fiscal year 2016, 197 SOEs failed to produce any profits and became the reason for the loss of Rs. 44.772 billion to the national exchequer ("197 state-owned enterprises run into losses, ministry admits", 2018) . The major SOEs such as Pakistan International Airlines (PIA), Steel Mills, PSO, Railways and WAPDA are also 
in moribund condition. According to an estimate, PIA alone loses around \$305 million a year and instead of adding in to the national treasury, it is causing a constant drain ("Loss-making State-Owned Entities Pose Economic Challenge to New Govt.”, 2013). These SOEs, when fail to operate effectively, are either privatized or reformed.

\section{Literature Review:}

Plethora of research has been carried out to properly understand the functioning and autonomy of SOEs operating in various countries. Autonomy can be defined as the capacity of a SOE to act independently while selecting the future orientations of its choice and freely translating them into reality through authoritative actions (Bach, 2018). It is a multi-dimensional concept and can be properly explained on the basis of different aspects and various dimensions (Bach, 2010). The level of autonomy in government organizations can vary from one organization to another. An organization can have autonomy in numerous dimensions such as organizational, managerial and economic autonomy (Verhoest et al. 2004). This study, however, focuses on three dimensions of autonomy which are autonomy in HRM, financial autonomy and policy autonomy of SOEs. According to Dunleavy et al. (2005), the autonomy in HRM can be defined as the liberty of SOE to choose the HRM practices of its own choice and make HR related decisions independently from other departments whereas, the autonomy of SOE in managing and allocating its funds is financial autonomy. According to Bach (2010) and Yesilkagit and Van Thiel (2008), the task autonomy is defined as the autonomy an organization has in development and implementation of the policy.

One of the major debates in most of the countries is that how much managerial autonomy should be provided to the state-owned enterprises (SOEs). Whenever a SOE is created as an independent legal body, it is assumed that if the operations of SOEs are carried out independently, there shall be a significant improvement in the efficiency of both the government and the SOE. Albeit multiple mechanisms are there that allow these SOEs to be controlled, but the actual autonomy that is provided to SOEs is affected by important political and economic factors (Bourants et al., 1993). According to Anastassopoulos (1985), three things can ensure the effective functioning of SOEs which include the setting of goals and strategy by state, having one authority to report and complete autonomy with zero political intervention. Lack of managerial autonomy is one of the major reasons behind the inefficient working of SOEs in both developed and developing countries (Gunasekar and Sarkar, 2019). The concept of autonomy can be used in different ways having the focus on formal and structural autonomy while studying government organizations and agencies (Roness, 2009).

On the basis of above discussion, it is safe to summarize that autonomy is a discretion that an agency or an organization exercises while deciding about matters related to itself which are considered important and he basic purpose of granting autonomy to the organizations is to create an environment that is decentralized which enhances the efficiency and effectiveness (Bach, 2010).

\section{Research Methodology:}

Both quantitative and qualitative techniques have been used to collect and analyze data. Primary data was collected to understand the actual state of autonomy of SOEs through a questionnaire and semi-structured interviews using the key informant approach. The questionnaires were filled by the Directors and CEO's of the organizations as they were the most appropriate people to know about the working of the organizations. The population comprised of all the SOEs of Pakistan. 60 SOEs were selected randomly out of which only 40 responded.

The questionnaire used was developed by a European Union organization known as Comparative Public Organization Data Base for Research and Analysis (COBRA). Only that portion of questionnaire which had in it the questions related to the HRM autonomy, financial autonomy and policy autonomy of organization was used. Human Resource Management autonomy was further divided into strategic and operational autonomy. Five dimensions of each of these types of HR autonomy were studied. Financial autonomy was divided into four dimensions and two dimensions of policy autonomy were analyzed.

Twenty semi-structured interviews of employees working at senior positions in Securities and Exchange Commission of Pakistan (SECP) and different SOEs were also carried out. This number of interviews was carried out because a saturation point was reached and respondents started to provide similar information. These interviews were transcribed, analyzed and conclusions were drawn. Along with this, analysis of legal documents comprising of Companies Ordinance 1984, Securities and Exchange Commission Act 1997, Code of Corporate Governance for both public and private sector was done to understand the formal autonomy granted to the SOEs.

\section{Data Analysis}

4.1 Tracing Formal autonomy of SOEs through analysis of legal documents:

Out of total forty SOEs, 33 SOEs were public companies registered under section 42 of the Companies Ordinance 1984 while 7 SOEs were statutory bodies having their own ordinance or act. The analysis of the 
Companies Ordinance 1984 and Public Sector Companies (Corporate Governance) Rules 2013 show that the SOEs of Pakistan are provided with a significant level of formal autonomy in HRM, financial management and policy making at both strategic and task level. However, numerous provisions were also found to keep check and balances on SOEs through SECP. These provisions have been discussed in the conclusion part.

i. $\quad$ Formal autonomy in Human Resource Management:

As per the sub-section 2 of the section 5 of the Public Sector Companies Rules 2013, the board of SOEs had the autonomy to choose CEO. Board of the SOEs was to recommend three members to the government and CEO will then be appointed by the board with the mutual agreement of the government. Thus, autonomy lies with the board when it comes to the appointment of the CEO as it is the board, comprising of independent members, which sends the recommendation list of three members to the government for the appointment of CEO and selection is made with its agreement. Similarly, sub-section 3 of the section 4 of Public Sector Companies (Corporate Governance) Rules 2013, gives the autonomy to the chief executive of SOE to look after the entire management, whether financial or related to any other matter. In this way, CEO of the SOE is autonomous in managing the financial management and the human resource management. Similarly, Sub-section 2 (i) of the section 196 of the Companies Ordinance 1984 has granted complete autonomy to the company directors to give the bonuses to the employees. Thus, there is a complete autonomy in compensating employees. As per the subsection 7(q) of the section 5 of the Public Sector Companies (Corporate Governance Rules) 2013, Board of the Directors of the public company can make the policies related to human resource management and can do succession planning freely. Similarly, from the sub-section 3 of the section 4 of Public Sector Companies (Corporate Governance) Rules 2013, it can be easily inferred that the maximum autonomy has been granted to the public companies when it comes to its human resource management at both operational and strategic level.

ii. Formal Policy Autonomy:

The board of directors of the public companies has also been granted with complete autonomy in policy making as well. As per the sub-section 7 of the section 5 of the Public Sector Companies (Corporate Governance) Rules, 2013, it is clearly stated that all the significant policies shall be formed by the Board of Directors of the company.

iii. Formal Financial Management Autonomy:

Numerous clauses related to the autonomy in financial management are present is both Companies Ordinance 1984 and Public Sector Companies (Corporate Governance) Rules 2013. The sub-section 2(d) of section 196 of the Companies Ordinance 1984 grants the complete autonomy to the board of the company or SOE to take loans and to incur capital expenditure. Similarly, in the sub-section 7(o) of the section 5, complete autonomy is also granted to the Board of Directors to make policies related to all the capital expenditure. Sub-section 7 of the section 5 of the Public Company Rules 2013 also clearly states that the Board of Directors of the public company is also free to get loans to some fixed extent, to purchase goods and services, and to carry out the marketing of the goods or services that it is producing. However, through the section 246 of the Companies Ordinance 1984 , every kind of company, including public company is required to submit the annual financial reports and such other additional reports after their audit to the Securities and Exchange Commission of Pakistan. This has been expressed in table 1.

Table 1: Formal Autonomy of Public Companies and Statutory Bodies

\begin{tabular}{|c|c|c|c|c|}
\hline & HRM autonomy & $\begin{array}{l}\text { Financial } \\
\text { Autonomy }\end{array}$ & $\begin{array}{l}\text { Policy autonomy at } \\
\text { Strategic Level }\end{array}$ & $\begin{array}{l}\text { Policy Autonomy at } \\
\text { task level }\end{array}$ \\
\hline $\begin{array}{l}\text { Public } \\
\text { Companies }\end{array}$ & $\begin{array}{l}\text { Maximum, but } \\
\text { SECP can change } \\
\text { the rules. }\end{array}$ & $\begin{array}{l}\text { Maximum, but } \\
\text { SECP can change } \\
\text { the rules. }\end{array}$ & $\begin{array}{l}\text { Maximum, but SECP } \\
\text { can change the rules. }\end{array}$ & $\begin{array}{l}\text { Maximum, but } \\
\text { SECP can change } \\
\text { the rules. }\end{array}$ \\
\hline Statutory Bodies & $\begin{array}{l}\text { Maximum, but } \\
\text { SECP can change } \\
\text { the rules, and } \\
\text { Federal } \\
\text { Government can } \\
\text { change the } \\
\text { directors who } \\
\text { have autonomy. }\end{array}$ & $\begin{array}{l}\text { Maximum, but } \\
\text { SECP can change } \\
\text { the rules, and } \\
\text { Federal } \\
\text { Government can } \\
\text { change the } \\
\text { directors who have } \\
\text { autonomy. }\end{array}$ & $\begin{array}{l}\text { Maximum, but SECP } \\
\text { can change the rules in } \\
\text { few statutory bodies, and } \\
\text { Federal Government can } \\
\text { change the directors who } \\
\text { have autonomy in all the } \\
\text { five statutory bodies. }\end{array}$ & $\begin{array}{l}\text { Maximum, but } \\
\text { SECP can change } \\
\text { the rules in few } \\
\text { statutory bodies, and } \\
\text { Federal Government } \\
\text { can change the } \\
\text { directors who have } \\
\text { autonomy in all the } \\
\text { statutory bodies. }\end{array}$ \\
\hline
\end{tabular}

\subsection{Actual Human Resource Management, Financial and Policy Autonomy of SOES}

4.2.1 Autonomy in HRM:

i. $\quad$ Strategic HR autonomy in setting level of salaries:

Out of total forty organizations, it was found that fourteen SOEs were completely autonomous in setting any general policy regarding the level of salaries of all employees without any kind of prior consent from concerned ministry while four SOEs had no autonomy at all. Sixteen had this autonomy for most of the staff members and 
only six SOEs could do so for some of the staff. The exact numbers and percentages are show in Table 2.

Table 2: Strategic autonomy in levels of salaries policy

\begin{tabular}{|l|l|}
\hline Level of Autonomy & Number of Organization \\
\hline No Autonomy & 4 \\
Autonomy for some staff & 6 \\
Autonomy for most staff & 16 \\
Autonomy for all staff & 14 \\
Total & 40 \\
\hline
\end{tabular}

ii. Strategic HR autonomy in setting conditions for promotions:

Only 12 SOEs had a complete autonomy to set in practice the general policy related to the promotion of all of its employees without any prior consent of the ministry while 17 SOEs had this autonomy for most of the employees. 7 SOEs were found to have this autonomy only for some of its staff members and 4 SOEs had no autonomy at all. Table 3 mentions the exact number of organization and their percentages.

Table 3: Strategic HR autonomy in conditions for promotions

\begin{tabular}{|l|l|}
\hline Level of Autonomy & Number of Organization \\
\hline No Autonomy & 4 \\
Autonomy for some staff & 7 \\
Autonomy for most staff & 17 \\
Autonomy for all staff & 12 \\
Total & 40 \\
\hline
\end{tabular}

iii. Strategic HR Autonomy in personnel evaluation policy:

Only seven SOEs had the complete autonomy to set the general policy related to the conditions for the evaluation of all of its employees without any prior consent of ministry. 26 SOEs could do so for most of its staff members while 4 SOEs had this autonomy for some of its employees. 3 SOEs didn't have such autonomy at all. Table 4 shows the number as well as percentages of organizations along with the level of autonomy which they had.

Table 4: Strategic HR Autonomy in personnel evaluation policy

\begin{tabular}{|l|l|}
\hline Level of Autonomy & Number of Organizations \\
\hline Valid No Autonomy & 3 \\
Autonomy for some staff & 4 \\
Autonomy for most staff & 26 \\
Autonomy for all staff & 7 \\
Total & 40 \\
\hline
\end{tabular}

iv. Strategic HR Autonomy in personnel appointment policy:

Four out of forty SOEs had a complete autonomy in setting general policy related to the appointment of all of its employees without any prior consent of concerned ministry while 20 SOEs could do so for most of its staff members. 13 SOEs had this autonomy for some members of its staff, while 3 SOEs had no autonomy at all. Table 5 mentions the number and percentages of organizations practicing various levels of this autonomy.

Table 5: Strategic Autonomy in personnel appointment policy

\begin{tabular}{|l|l|}
\hline Level of Autonomy & Number of Organizations \\
\hline No Autonomy & 3 \\
Autonomy for some staff & 13 \\
Autonomy for most staff & 20 \\
Autonomy for all staff & 4 \\
Total & 40 \\
\hline
\end{tabular}

v. Strategic HR Autonomy in downsizing policy:

Four SOEs were found to be completely autonomous in setting general policies pertaining to downsizing of all of its employees without any kind of prior consent of concerned ministry while 16 SOEs could do so for most of its employees. 13 SOEs had this autonomy for some of its staff members and 7 SOEs were completely deprived from such autonomy. Table 6 mentions the level of autonomy practiced by the exact number of organizations. 
Table 6: Strategic HR Autonomy in downsizing policy

\begin{tabular}{|l|l|}
\hline Level of Autonomy & Number of Organizations \\
\hline No Autonomy & 7 \\
Autonomy for some staff & 13 \\
Autonomy for most staff & 16 \\
Autonomy for all staff & 4 \\
Total & 40 \\
\hline
\end{tabular}

vi. Operational HR autonomy in setting level of specific employee salary:

Only five organizations out of forty were found to have complete autonomy in setting the salaries for all the employees without any prior consent of minister or parent ministry while 17 had this autonomy for some of its employees. 9 SOEs had no such autonomy at all and remaining 9 had this autonomy for most of its employees. These numbers and percentages of organizations are expressed in table 7.

Table 7: Operational HR autonomy in setting level of specific employee salary

\begin{tabular}{|l|l|}
\hline Level of Autonomy & Number of Organizations \\
\hline No Autonomy & 9 \\
Autonomy for some staff & 17 \\
Autonomy for most staff & 9 \\
Autonomy for all staff & 5 \\
Total & 40 \\
\hline
\end{tabular}

vii. Operational HR autonomy in specific employee promotion:

Four organizations had the autonomy to decide about promotion of all of its employees without any prior consent while 23 could do so for the promotion of some of its staff members. 9 organizations had this autonomy for maximum staff members and 4 organizations had no such autonomy at all. Table 8 mentions the exact numbers and percentages of the organizations having different levels of autonomy.

Table 8: Operational HR autonomy in specific employee promotion

\begin{tabular}{|l|l|}
\hline Level of Autonomy & Number of Organizations \\
\hline No Autonomy & 4 \\
Autonomy for some staff & 23 \\
Autonomy for most staff & 9 \\
Autonomy for all staff & 4 \\
Total & 40 \\
\hline
\end{tabular}

viii. Operational HR autonomy in specific employee evaluation:

Only seven organizations had the complete autonomy to take decisions regarding the evaluation of all of its employees without any kind of prior consent while 20 organizations could do so for most of its staff members and 9 of the total organizations had a very limited autonomy and could take such decisions for some of its employees only. 4 organizations had no such autonomy at all. The exact number and percentages of organizations practicing this level of autonomy is shown in table 9.

Table 9: Operational HR autonomy in specific employee evaluation

\begin{tabular}{|l|l|}
\hline Level of Autonomy & Number of Organizations \\
\hline No Autonomy & 4 \\
Autonomy for some staff & 9 \\
Autonomy for most staff & 20 \\
Autonomy for all staff & 7 \\
Total & 40 \\
\hline
\end{tabular}

ix. Operational HR autonomy in specific employee appointment:

Seven SOEs were found to have complete autonomy in taking decisions regarding the appointment of all of its employees without any kind of prior consent. 19 organizations had limited autonomy and could take such decision for some of its staff members. 7 organizations had this autonomy for most of the staff members and 7 organizations had no such autonomy at all. These numbers of organizations and their percentages are in table 10. 
Table 10: Operational HR autonomy in specific employee appointment

\begin{tabular}{|l|l|}
\hline Level of Autonomy & Number of Organizations \\
\hline No Autonomy & 7 \\
Autonomy for some staff & 19 \\
Autonomy for most staff & 7 \\
Autonomy for all staff & 7 \\
Total & 40 \\
\hline
\end{tabular}

x. Operational HR autonomy in dismissing single employee:

When it comes to dismissing or discharging employees, only five organizations had complete autonomy to discharge all of its employees without any prior consent of ministry and 20 had limited autonomy and could dismiss only some of its employees without any kind of prior consent. 7 organizations had this autonomy for most of its staff members and 8 organizations had no autonomy at all. These numbers are mentioned in table 11 . Table 11: Operational HR autonomy in dismissing single employee

\begin{tabular}{|l|l|}
\hline Level of Autonomy & Number of Organizations \\
\hline No Autonomy & 8 \\
Autonomy for some staff & 20 \\
Autonomy for most staff & 7 \\
Autonomy for all staff & 5 \\
Total & 40 \\
\hline
\end{tabular}

4.2.2 Financial Autonomy:

i. Financial autonomy in taking loans:

It was found that only four SOEs had a complete autonomy to take loans without any conditions set by concerned ministry while 29 of the total organizations had no autonomy in taking loans at all. 7 organizations had the autonomy within the conditions set by the minister or ministries. The exact number and percentage of organizations is shown in table 12 .

Table 12: Financial autonomy in taking loans

\begin{tabular}{|l|l|}
\hline Level of Autonomy & Number of Organizations \\
\hline No Autonomy & 29 \\
Autonomy within conditions set from above & 7 \\
Autonomy without conditions & 4 \\
Total & 40 \\
\hline
\end{tabular}

ii. Autonomy in shifting between personnel and running cost budgets:

When it comes to shift personnel and running cost budgets, only 13 organizations had the complete autonomy to do so without any kind of predetermined conditions set by the minister, ministries or president. 7 organizations were found to have limited autonomy and could do so within the conditions set by the higher authorities. 20 organizations had no autonomy at all. Table 13 shows these exact figures and varying levels of autonomy that organizations had

Table 13: Autonomy in shifting between personnel and running cost budgets

\begin{tabular}{|l|l|}
\hline Level of Autonomy & Number of Organizations \\
\hline No Autonomy & 20 \\
Autonomy within conditions set from above & 7 \\
Autonomy without conditions & 13 \\
Total & 40 \\
\hline
\end{tabular}

iii. Autonomy in setting tariffs:

Only 11 SOEs had a complete autonomy in setting the tariffs of their products and services without any conditions set by relevant ministry while 16 were not autonomous at all. 13 organizations had a limited autonomy and could do so within predetermined conditions set by the parent or relevant minister or ministry. The number of organizations and the level of autonomy practiced by them are expressed in table 14 .

Table 14: Autonomy in setting tariffs

\begin{tabular}{|l|l|}
\hline Level of Autonomy & Number of Organizations \\
\hline No Autonomy & 16 \\
Autonomy within conditions set from above & 13 \\
Autonomy without conditions & 11 \\
Total & 40 \\
\hline
\end{tabular}

$i v$. Autonomy in shifting between personnel-running cost and investments budgets:

Complete autonomy in shifting between personnel running cost and investment budgets without any predetermined conditions imposed by ministry was enjoyed by only 6 SOEs. 27 of the SOEs had no autonomy at all while 7 SOEs had a limited autonomy and they could do so with in the conditions set by the parent minister, 
ministry or relevant ministry. Table 15 shows the exact number of organization and the level of autonomy practiced by them.

Table 15: Autonomy in shifting between personnel-running cost and investments budgets

\begin{tabular}{|l|l|}
\hline Level of Autonomy & Number of Organizations \\
\hline No Autonomy & 27 \\
Autonomy within conditions set from above & 7 \\
Autonomy without conditions & 6 \\
Total & 40 \\
\hline
\end{tabular}

4.2.3 Policy Autonomy:

i. Autonomy in choice of target groups of policy:

4 SOEs were completely autonomous in taking decision regarding the target groups of policy without any consultation with concerned ministry while 20 SOEs had some but not complete autonomy and they could do so after the slight involvement and minor restriction of minister/parent ministry. Autonomy of 16 SOEs was even more curtailed and they could do so after explicit consultation with their minister/parent ministry. The exact number of organizations and the level of autonomy practiced by them are expressed in table 16 .

Table 16: Autonomy in choice of target groups of policy

\begin{tabular}{|l|l|}
\hline Level of Autonomy & Number of Organizations \\
\hline Autonomy after consultation with minister/parent ministry & 16 \\
Autonomy with minor restriction & 20 \\
Complete Autonomy and no involvement of ministry & 4 \\
Total & 40 \\
\hline
\end{tabular}

ii. Autonomy in fulfillment of tasks:

Complete autonomy in the way the tasks are implemented was enjoyed by 13 SOEs and they could do so without any kind of consultation with parent minister or ministry. 20 SOEs were considerably less autonomous in that and took such decisions after slight consultation with ministry and 4 SOEs had to explicitly consult with the parent ministry thus compromising their autonomy even more. 3 SOEs had no such autonomy at all and such decisions were taken by parent ministry. These numbers and the level of autonomy practiced by the number of organizations are shown in table 17

Table 17: Autonomy in fulfillment of tasks

\begin{tabular}{|l|l|}
\hline Level of Autonomy & Number of Organizations \\
\hline No autonomy and ministry takes decision & 3 \\
Autonomy after explicit consultation with ministry & 4 \\
Autonomy but ministry is slightly & 20 \\
Involved & \\
Complete autonomy & 13 \\
Total & 40 \\
\hline
\end{tabular}

\subsection{Interview Analysis}

Through the analysis of interviews, different themes were identified that were relevant to the reasons behind the lack of autonomy and the suggestions that could improve the situation of autonomy of SOEs.

4.3.1 Reasons behind lack of autonomy of SOEs

i. $\quad$ The important role of SECP and decline in its autonomy:

It was found that SECP has a crucial role to play in the governance of SOEs and is responsible for the enforcement of Companies Ordinance, 1984. It is the responsibility of the Registrars and Additional Registrars of the Company Registration Offices (CROs) of SECP which are present in eight major cities of Pakistan including Islamabad, Karachi, Lahore, Faisalabad, Multan, Peshawar, Quetta and Sukkur to enforce all the rules and regulations in companies. Besides this, SECP is also responsible for maintaining all the documents such as memorandum of association etc. The record of these documents also helps the SECP to ensure the enforcement of the provisions mentioned in the Companies Ordinance 1984. Therefore, it also becomes the responsibility of SECP to ensure autonomy of SOEs as guaranteed by the ordinance. However, it was found that the autonomy of SECP in performing their tasks is also on the decline due to which respondents were of the view that SECP cannot regulate the working of SOEs and other companies and ensure their autonomy when its own autonomy is at not there. 
ii. Composition of Board of Directors of SOE and Policy Board of SECP as major hurdle in enforcement of corporate laws in SECP:

It was also found that the major hurdle in the enforcement of autonomy related provisions in SOEs was that the Board of Directors of SOEs and the Policy Board of SECP are mostly composed of civil servants. These civil servants are not only in good terms with each other but are also inadequately trained to operate effectively in a corporate setting. They lack in the necessary corporate experience and are trained to run a government department which proves to be the major hurdle in the implementation and enforcement of the Companies Ordinance 1984. Moreover, their nature to oblige political elite to secure their career related interests opens a window for politicians to meddle in the affairs of SOEs which results in the loss of autonomy of SOEs.

iii. Autonomy within "rules".

Some of the interviewees mentioned that SOEs were autonomous but they could only exercise their autonomy within the rules and provisions present in relevant legal documents.

iv. Autonomy dependent upon performance of SOEs.

Through the interviews, it was also found that those SOEs that have always generated profits, distributed dividends and have never been a liability on the government are more autonomous as compared to those that are financially weak and not profitable.

v. Appointment of Board of Directors and CEOs by government:

It was found that autonomy of most of SOEs was compromised due to a significant involvement of government in the functioning of these SOEs. According to the official belonging to Lahore Electric Supply Company (LESCO), the major reason behind the lack of autonomy at LESCO was the frequent government interventions. According to the respondent belonging to National Fertilizers Marketing Limited (NFML), the major reason behind the lack of autonomy of SOEs is the appointment of the heads of these public sector organizations by the government on the basis of favoritism. As per one of the interviewee, Board of Directors is appointed by the government for an unidentified period of time which hurts the autonomy to a great extent. As a result of this, the directors stay at their positions for as long as the period of ten years. Also, the government is involved in the appointment of the CEO which hurts the autonomy of SOEs.

vi. Dependence of SOEs on government and autonomy:

Analysis of interviews revealed that another important factor that shrinks the autonomy of SOEs is the dependence of large, unprofitable SOEs on government for resources particularly the financial ones. It was quoted by the official of SECP that since it has become a tradition within our state to give large sum of money in form of subsidy or bailout packages to SOEs like Pakistan Steel Mills and PIA, the autonomy of the SOEs has therefore been compromised.

vii. Different characteristics of SOEs and autonomy:

Size and political visibility were also identified by the interviewees as major reasons behind the lack of autonomy of SOEs. Numerous respondents were of the view that the organizations that had large business operations and could support a large number of employees were the ones that had more political appeal and visibility. These organizations become a lucrative place for the political and ruling elite to get the people of their choice hired and enhance political capital and maintain their vote bank. This eventually reduces the HR autonomy of organizations and makes them more unprofitable which further increase their dependence on government for financial resources thus reducing their financial autonomy as well.

viii. Inapplicability of provisions of Companies Ordinance:

It was also found through the interviews that numerous sections of Companies Ordinance 1984 like section 183 and section 503 of companies ordinance were not applicable on SOEs due to which the power of SECP is reduced when it comes to regulation of SOEs and it becomes more convenient for government to intervene in the functioning of SOEs.

4.3.2 Recommendations to improve the autonomy of SOEs

Following recommendation to create a balance between real and formal autonomy of SOEs as well as to improve their performance have been proposed in the light of data collected through interviews.

i. No bureaucrats in Policy Board of SECP and in Board of Directors of SOEs:

Policy Board of SECP, which is a regulating body, should either comprise of no bureaucrats (civil servants appointed through competitive exams) at all or should have very less number of bureaucrats who are completely impartial and unbiased in their conduct. Similarly, there must be no involvement of bureaucrats in the Board of Directors of SOEs as their presence enables the political elite to make unnecessary interventions in the working of SOEs which compromises their autonomy and performance.

ii. Curbing political intervention:

Frequent political intervention of the government must be curtailed on immediate basis. It was even suggested that either there must be some legislation in this regard or the Honorable Supreme Court of Pakistan should take a strict notice of this malpractice.

iii. Reforms in SOEs: 
There is a dire need to implement IT based reforms in SOEs, reduce rigidity that was found in their hierarchy by implementing team based structure and make performance based recruitment and promotions so that profitability of SOEs can be enhanced and their financial dependence on the government, which also reduces their autonomy, could minimized.

iv. Appointment of independent directors in the board of SOE:

Independent directors, who are in the board of only one SOE should be appointed, and provision that allows the director of one SOE to be the director of another SOE must be removed.

v. Ensuring implementation of Code of Corporate governance for Public Enterprises:

The implementation of Code of Corporate Governance for Public Enterprises must be ensured. To ensure this, SECP must be empowered so that it can play its due role.

vi. Training of the officials of SOEs and increasing their sensitivity and raising their awareness:

Senior managers in SOEs must not only be trained to say no to their political bosses, but also be sensitized about importance of autonomy and the ways through which an SOE can lose it.

\section{Discussion and Conclusion}

Autonomy is indispensable for the financial performance of the SOEs (Groves et al. 1994; Cheng et al. 2000). This research study achieves multiple objectives and answers different questions pertaining to autonomy of SOEs. The analysis of Companies Ordinance 1984, SECP Act 1997, Public Sector Companies (Corporate Governance) Rules 2013, and statutes through which statutory bodies are created, it was unveiled that a significant amount of formal autonomy has been granted to the SOEs. Sub-section 7 of the section 5 of Public Company Rules 2013, sub-section 2 (i) of the section 196 of the Companies Ordinance 1984 and sub-section 2(d) of section 196 of the Companies Ordinance 1984 show that maximum HRM and financial autonomy has been provided to the Board of Directors of the Public Sector Companies. However, it was also revealed that the formal autonomy granted through the Companies Ordinance 1984, Public Sector Companies (Corporate Governance Rules) and statutes was not actually exercised by SOEs. Some of the SOEs were autonomous in few dimensions of autonomy in HRM but majority were not autonomous in all the dimensions of HRM. Similarly, very less number of SOEs was completely autonomous in all the dimensions of financial and policy autonomy. It was also found that the SECP Act 1997 ensured the control of SECP over the companies, both public and private. Part VI, section 20 and sub-section 4(j) and 4(1) and section 21, sub-section 1(a) (ii) of the SECP Act empowered SECP to regulate substantial acquisition of share, takeovers, mergers, professional organizations related to insurance business and carry out inquiries and audits of Stock Exchanges. SECP is also responsible for considering and recommending changes in the laws and constitutions of companies, corporate and security bodies. Section 39, 40, 40(A) and 40(B) of the SECP Act 1997 also allows the SECP to make rules, regulations, codes and guidelines for the companies. Also, article 506, 506(A), and 506 (B) of the Companies Ordinance, the Federal Government and SECP can make rules and regulations that may affect the functioning of any company, be it a public or private. From these sections, it is also clear that state has also exercised its control over SOEs through institutions like SECP. However, unnecessary political interventions in SOEs, dependence on government for resources, size, nature of tasks, political visibility, poor financial performance and lack of independent members in the board of directors of SOEs were identified as some of the factors that further reduced the autonomy of SOEs. These reasons have also been identified by Lioukas, Bourantas and Papadakis (1993). To conclude, it can be said that SOEs in Pakistan have been given autonomy, and, at the same time, state also keeps a control on these SOEs through different provisions in SECP Act and Companies Ordinance as discussed earlier. However, the autonomy of SOEs is further breached due to the factors identified above and the need of hour is to ensure that balance between formal and actual autonomy of SOE is achieved and they are made independent in their functioning.

\section{References}

Aharoni, Y. (1986), The Evolution and Management of State-Owned Enterprises, Ballinger Publishing Co, Cambridge.

Aharoni, Y. (1981), "The evolution and management of state-owned enterprises", Administrative Science Quaterly 33 (1), 165-167.

Anastassopoulos, J.P. (1985), "SOEs between autonomy and dependency", Journal of Public Policy 5(4), 521539.

Bach, T. (2010), "Policy and management autonomy of federal agencies in Germany", in Lægreid P. and Verhoest K. (Ed.), Governance of Public Sector Organizations, Palgrave Macmillan, London, pp. 89-110.

Bach, T. (2018). Administrative Autonomy of Public Organizations. In A. Farazmand (Ed.), Global Encyclopedia of Public Administration, Public Policy, and Governance (pp. 171-179). Cham: Springer International Publishing.

Boycko, M., Shleifer, A. and Vishny, R.W. (1996), "A theory of privatisation", Economy Journal 106, 309-309. 
Braadbaart, O., Eybergen, N.V. and Hoffer, J. (2007), "Managerial Autonomy: Does it matter for the performance of water utilities", Public administration \& Development 24, 111-121.

Cheng H, Cheng H, Nugent JB, Jiqeng Q. 2000.Managerial Autonomy in a Transition Economy_Determinants and Effects: Some EvidenceFrom China's TVE's. University of Southern California: Los Angeles.

Chodhury, M.Z. (2012), "Is privatization the solution for state-owned enterprises? ", The Express Tribune, 6 August, pp. 12.

David, P.A. (1994), "Why are institutions the 'carriers of history'?: path dependence and the evolution of conventions, organizations and institutions", Structural Change and Economic Dynamics 5(2), 205-220.

DiMaggio, J. P. and Powell, W. W. (1983), "The Iron Cage Revisited: Institutional Isomorphism and Collective Rationality in Organizational Fields", American Sociological Review 48 (2), 147-160.

Dunleavy, P., Margetts, H., Bastow, S., \& Tinkler, J. (2005). New public management is dead - Long live digital-era governance. Journal of Public Administration Research and Theory 16(3), 467-494.

Garner, M. R. (2005), "The Relationship Between Government and Public Enterprise", in Reddy, G.R. (Ed.), Government and Public Enterprise. Essays in Honour of Professor V. Ramanadham, Routledge, London, pp. 4-23.

Groves T, Hong Y, Mcmillan J, Naughton B. 1994, “Autonomy and incentives in chinese state enterprises", Quarterly Journal of Economics 109(1), 183-209.

Gunasekar, S. and Sarkar, J. (2019), "Does autonomy matter in State Owned Enterprises? Evidence from performance contracts in India", Economics of Transition and institiutional change 27(3), 763-800.

Haider, M. (2018), "197 state-owned enterprises run into losses, ministry admits", The News, 17 November.

Khan, A. (2008), "Introduction: Reinventing public enterprises" in Public Enterprises: Unresolved Challenges and New Opportunities, Publication based on the Expert Group Meeting on Re-inventing Public Enterprise and their Management, New York, pp. 3-8.

Khan, F. (2007), "Corruption and the decline of the state in pakistan", Asian Journal of Political Sciences 15(2), 219-247.

Labra, A. (1980), "Public Enterprise in an Underdeveloped and Dependent Economy", in Baumol, W.J. (Ed.), Public and private enterprise in a mixed economy, Palgrave Macmillan, London, pp. 36-37.

Lioukas, S., Bourantas, D., \& Papadakis, V. (1993), "Managerial autonomy of state-owned enterprises: determining factors", Organization Science 4(4), 645-666.

Dawn (2013), "Loss-making state-owned entities pose economic challenge to new govt", 10 June), p. 5.

Maheshwari, S. (1974), "Administrative reforms in Pakistan", The Indian journal of political science 35(2), pp. 144- 156.

Rana, S. (2011), "White elephants live on: Govt interference ruined state-owned enterprises", The Express Tribune, 2 December, p. 7.

Roness, P, G. (2009), "Handling theoretical diversity on agency autonomy", in Roness, P.G.and Saetren, H. (Ed.), Change and Continuity in Public Sector Organizations, Bergen, Fabokforlaget, pp. 45-62.

Sexty, R. W. (1980), "Autonomy Strategies of Government Owned Business Corporations in Canada", Strategic Management Journal 1(4), 371-384.

Smith, C. and Trebilcock, J. (2001), "State-owned enterprises in less developed countries: Privatization and alternative reform strategies", European Journal of Law and Economics 12, 217-252.

Verhoest, K., Peters, B.G., Bouckaert, G. and Verschuere, B.(2004), "The study of organisational autonomy: a conceptual review", Public Administration and Development 24(2), $101-118$.

Wintrobe,R. (1987), "The Market for Corporate Control and the Market for Political", Journal of Economy and Organization 3(1), 435-436.

Yesilkagit, K. and Thiel, V. (2008), "Political Influence and Bureaucratic Autonomy", Public Organization Rev 8, 137-153. 